\title{
Role of Primary Health Care in the Face of the Coronavirus Pandemic
}

\author{
Claribel Plain Pazos ${ }^{1 *}$, Carmen Rosa Carmona Pentón ${ }^{1}$, Anisbel Pérez de Alejo Plain², Malena \\ Nodarse Quintero ${ }^{3}$ and Nereyda A Caraballo Moya ${ }^{4}$ \\ ${ }^{1}$ Specialist of II Degree in Comprehensive General Medicine, Assistant Professor, Faculty of Medical Sciences of Sagua la Grande, \\ Villa Clara, Cuba \\ ${ }^{2} 2^{\text {nd }}$ Year Student of Medicine, Faculty of Medical Sciences of Sagua la Grande, Villa Clara, Cuba \\ ${ }^{3}$ Bachelor of Education, Instructor teacher, Cuba
}

${ }^{4}$ Specialist of I Degree in Comprehensive General Medicine, Assistant Professor, Faculty of Medical Sciences of Sagua la Grande, Villa Clara, Cuba

*Corresponding author: Claribel Plain Pazos, Specialist of II Degree in Comprehensive General Medicine, Faculty of Medical

Sciences of Sagua la Grande, Villa Clara, Cuba

\section{ARTICLE INFO}

Received: April 13, 2020

Published: April 24, 2020

Citation: Claribel PP, Carmen Rosa Carmona P, Anisbel Pérez de AP, Malena Nodarse Q, Nereyda A Caraballo M. Role of Primary Health Care in the Face of the Coronavirus Pandemic. Biomed J Sci \& Tech Res 27(2)2020. BJSTR. MS.ID.004474.

\section{ABSTRACT}

Coronaviruses are a wide family of viruses that can cause various conditions. COVID-19 is the most recently discovered infectious disease caused by the coronavirus. Primary Health Care in Cuba is maintained as the central axis of the Health System, with coverage and universal access for the entire population. It is the responsibility of the Basic Health Team, made up of the family doctor and nurse, as health promoters closest to the community, to guide the population in this regard, as well as to explain the protection measures that they must adopt to avoid contagion of the illness. Only with health promotion and prevention can to stop the Coronavirus.

Keywords: Coronavirus; COVID-19; Primary Health Care

\section{Introduction}

Coronaviruses (CoV) are a broad family of viruses that can cause a variety of conditions, from the common cold to more serious illnesses, such as a severe acute respiratory syndrome [1]. COVID-19 is the infectious disease caused by most recently discovered coronavirus. Both the new virus and the disease were unknown before the outbreak in Wuhan, China, in December 2019 [2]. The concept of Primary Health Care (PHC) was consolidated in the International Conference on Primary Health Care, Alma Ata, 1978. In point VI of the Declaration of this conference, it is defined as "... the first level of contact of the individual, the family and the community with the national health system, which brings health care as close as possible to where the population lives and works and constitutes the first element of a permanent health care process" [3]. PHC in Cuba is maintained as the central axis of the Health System, because there is total coverage and universal access for the entire population, it is the first contact, it provides comprehensive, integrated, dispensed and continuous care, it makes family counseling possible and community, actions are aimed at promotion and prevention, promote appropriate care according to the needs of care, also, assesses the organization and actions to be carried out in accordance with the strategies of the Cuban Health System and the needs of the population in consistent with available resources, guarantees and organizes adequate human resources according to the needs of the population, promotes and maintains inter sectoral actions as a basic principle, and the family doctor and nurse model is based on a political, legal framework and solid institutional [4].

The APS leads the health system in Cuba. The health systems led by the PHC allow us to consolidate and maintain the progress made, as well as to face the new health and development challenges [3].The role of PHC in the face of the coronavirus pandemic, according to the authors, rests on two fundamental aspects: Firstly, 
the education of the population with all the measures to be adopted to prevent the imminent possibility of contagion of the disease with the objective that they are capable of protecting themselves and, in second order, but not least, the investigation, isolation and control of all persons who may constitute a risk of development and expansion of the disease, also applying the measures of International Health Control. As well as the immediate diagnosis of symptomatic cases for transfer, confirmation and isolation in a healthcare unit, avoiding transmissibility and providing timely treatment. It is of utmost importance that the population acquire perception of the risk to which they are exposed. It is the responsibility of the Basic Health Team (EBS) integrated of the family doctor and nurse, as health promoters closest to the community, to guide the population in this regard, as well as to explain the protection measures that they must adopt to avoid the spread of the disease. Given the high contagiousness of this disease, the population must take responsibility for its self-protection and the protection of its family, but that only happens with adequate health education.

ISSN: 2574-1241

DOI: $10.26717 /$ BJSTR.2020.27.004474

Claribel Plain Pazos. Biomed J Sci \& Tech Res

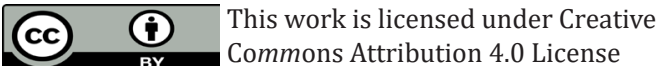

Submission Link: https://biomedres.us/submit-manuscript.php
Cuba, over the years, has demonstrated the strength of its health system. An example of this is the eradication of diseases such as malaria, schistosomiasis, yellow fever, which despite being endemic in countries where there is Cuban collaboration, and having presented in Cuba incidence of these imported diseases, no transmissibility has been reported of them thanks to the application of the International Health Control Program. In the face of this new epidemic, this program is applied in a similar way, but taking into account the specific characteristics of the COVID-19 disease.

\section{References}

1. https://www.who.int/es/healthtopics/coronavirus.

2. https: / /www.who.int/es/emergencies / diseases/novelcoronavirus-2019/advice-for-public/q-a-coronaviruses

3. Delgado García G, Rojas Ochoa F (2014) Antecedentes de la atención primaria de salud en Cuba En: Álvarez Sintes, Medicina General Integral. Salud y Medicina La Habana: Editorial Ciencias Médicas 1(3): 59-68.

4. Álvarez Sintes R (2014) Renovación de la atención primaria de salud En: Álvarez Sintes, Medicina General Integral. Salud y Medicina La Habana: Editorial Ciencias Médicas 1(3): 77-87.

$\begin{array}{ll}\text { BIOMEDICAL } & \text { Assets of Publishing with us } \\ \text { RESEARCHES } & \text { - Global archiving of articles } \\ \text { - Immediate, unrestricted online access } & \text { - Rigorous Peer Review Process } \\ & \text { - Authors Retain Copyrights } \\ & \end{array}$

